\title{
Komunikasi Interpersonal Komunitas Waria
}

\section{Taufik Naipon}

\author{
Rosleny Babo \\ Universitas Muhammadiyah Makassar \\ roslenybabo@unismuh.ac.id
}

\author{
Jamaluddin Arifin \\ Universitas Muhammadiyah Makassar \\ jamaluddinarifin@unismuh.ac.id
}

\begin{abstract}
ABSTRAK
Jenis penelitian kualitatif deskriptif, metode yang berlandaskan pada filsafat postpositivisme yang di gunakan untuk meneliti pada kondisi objek yang alamiah dengan tujuan untuk memahami suatu fenomena dalam konteks sosial dengan mengedepankan proses interaksi komunikasi yang mendalam antara peneliti dengan fenomena yang diteliti. Hasil dari penelitian adalah komunitas waria di kabupaten banteng eksis dengan kegiatan atau pekerjaan yang mereka tekuni secara berkelompok. Komunitas waria daerah ini memiliki bentuk komunikasi interpersonal seperti kebiasaan-kebiasaan dalam berkelompok dan bahasa khusus atau simbol yang di gunakan dalam berkomunikasi yang tidak di pahami oleh banyak orang saat bertukar informasi. Pendidikan seks diperlukan, pada kalangan usia dini. Hal ini diperlukan karena untuk memberikan penjelasan dan pengarahan, agar dapat mengidentifikasi diri sesuai dengan jenis kelamin mereka untuk mencegah terjadinya transgender.
\end{abstract}

Kata Kunci : Komunitas, Waria, Komunikasi, Interpersonal,

\section{PENDAHULUAN}

Di kalangan masyarakat saat ini fenomena komunitas waria dapat dijumpai di setiap sudut kota, mereka berbaur dengan masyarakat setempat. Banyak masyarakat yang menerima kehadiran mereka meskipun komunitas waria masih dianggap sebagai suatu gangguan, tetapi tidak sedikit pula yang menolak kehadiran mereka. Komunitas waria dalam masyarakat merupakan komunitas yang eksklusif karena mereka memiliki komunitas tersendiri dengan pola-pola kehidupan yang agak berbeda dengan masyarakat pada umumnya. Interaksi sosial dengan masyarakat pada umumnya bersifat negatif, terutama pandangan masyarakat terhadap komunitas waria.

Pandangan masyarakat terhadap komunitas waria merupakan sebuah fenomena sosial tersendiri bagi masyarakat dimana sampai saat ini komunitas waria adalah salah satu komunitas yang terpinggirkan. Banyak orang yang memandang sebelah mata terhadap eksistensi waria, Proses sosialisasi yang tidak sempurna menggiring komunitas waria untuk berubah. Sikap ini berawal dari lingkungan keluarga, dan lingkungan tempat 
tinggalnya dan menyebar ke masyarakat pada umumnya. Akibatnya mereka membentuk solidaritas mekanis yang ditandai dengan adanya kesadaran kolektif yang merasa senasib, dimana solidaritas ini merupakan kegiatan mempertahankan eksistensi mereka dalam berinteraksi sosial dengan lingkungan masyarakat yang mereka hadapi. Bentuk-bentuk solidaritas itu bisa dilihat dalam aktivitas ekonomi mereka yang kebanyakan bekerja di salon sebagai tukang cukur dan penata rias pengantin. Dalam aktivitas olahraga misalnya, mereka melakukannya hanya dalam kelompoknya saja tanpa bergabung dengan kelompok lain.

Kehadiran komunitas waria tetaplah hari ini masih diterima secara dilematis. Pada satu sisi waria diterima namun di sisi yang lain mereka ditolak. Penolakan terhadap waria tersebut terutama dilakukan oleh masyarakat strata sosial atas. bahwa masyarakat strata sosial atas ternyata lebih sulit memahami eksistensi waria, mereka memiliki pandangan negatif terhadap waria dan enggan bergaul dengan waria dibanding masyarakat strata sosial bawah yang lebih toleran. Komunitas waria diterima atau ditolak di dalam masyarakat akan sangat ditentukan dari bagaimana mereka membangun interaksi dan komunikasi dengan masyarakat untuk menjadi bagian dari lingkungan sosial itu sendiri. Sehingga keputusan masyarakat untuk menolak atau menerima kehadiran waria, pada akhirnya ditentukan oleh kemampuan seorang waria, baik secara individual maupun kolektif dalam merepresentasikan perilakunya sehari-hari.

\section{LANDASAN TEORI}

Manusia yang diciptakan di muka bumi ini hanya ada dua jenis kelamin yaitu wanita dan pria. Yang membedakan diantara keduanya adalah organ reproduksi berupa vagina dan rahim untuk mengandung, melahirkan, menyusui yang tidak mampu dilakukan oleh seorang pria inilah yang disebut dengan tugas atau peranan seoarang wanita, ibu, atau perempuan. Adapun pria yang merupakan lawan jenis dari wanita yang mampu memproduksi sperma dan memiliki organ reproduksi berupa penis. Sedangkan waria (dari wanita pria) atau wadam (dari wanita hawa) dalam pengertian istilah umum diartikan sebagai laki-laki yang lebih suka berperan sebagai perempuan dalam kehidupannya sehari-hari. Sedangkan dalam bahasa arab Waria dikenal dengan $A l$ Mukhonats yang ditinjau dari dua sisi yaitu pertama kodratnya sejak lahir, seperti memiliki postur tubuh yang menyerupai wanita, lisan yang apabila berbicara menyerupai wanita dan lainnya. Kemudian yang kedua yaitu dilahirkan dengan normal seperti lakilaki kemudian berusaha untuk berbicara, bergerak, bertabiat dan berhias seperti wanita. 
Dalam Juwilda juga dipaparkan bahwa waria biasa juga dikenal dengan istilah transgender yaitu untuk mendeskripsikan orang yang melakukan, merasa, berpikir atau terlihat berbeda dari jenis kelamin yang ditetapkan saat mereka lahir. Transgender tidak menunjukkan bentuk spesifik apapun dari orientasi seksual orangnya. orang-orang trasnsgender dapat saja mengidentifikasikan dirinya sebagai heteroseksual, homoseksual, biseksual, poliseksual,atau aseksual. Menurut Kaplan, Sadock dan Grebb (dalam Meta, 2011) ada beberapa factor yang memepengaruhi seseorang menjadi waria yaitu :

1. Factor biologis

Penjelasan biologis munculnya gagngguan identitas gender sangat berkaitan dengan hormone dalam tubuh. Tubuh manusia menghasilkan hormone testosterone yang mempengaruhi neuron otak, berkonstribusi terhadap maskulinitas otak yang terjadi pada area sperti hipotalamus, dan sebaliknya dengan hormone feminim. Namun hingga saat ini, pengaruh hormon terhadap munculnya gangguan masih menjadi kontroversi.

2. Factor psikososial

Seorang anak akan mengembangkan identitas gendernya selaras dengan apa yang diajarkan pada mereka selama masa pengasuhan. Menurut pendekatan psikososial, terbentuknya gangguan identitas gender dipengaruhi oleh interaksi tempramen anak, kualitas, dan sikap orang tua. Secara budaya, masih terdapat larangan bagi anak lakilaki untuk menunjukkan perilaku feminism, dan anak perempuan menjadi tomboy, termasuk dengan perbedaan terhadap pakaian dan mainan untuk anak laki-laki dan perempuan

Selain dua factor diatas dalam Hanger (2010) ditambahkan lagi satu factor yang juga mempengaruhi seseorang menjadi waria yaitu factor sosiogenik. Factor sosiogenik tersebut diuraikan seperti keadaan lingkungan sosial yang kurang kondusif akan mendorong adanya penyimpangan perilaku seksual. Berbagai stigma dan pengasingan masyarakat terhadap komunitas waria memposisikan diri waria membentuk atau berkelompok dengan komunitasnya. Kondisi tersebut ikut mendorong para waria untuk bergabung dalam komunitasnya dan semakin matang menjadi seorang waria baik dalam perilaku maupun orientasi sexualnya.

Waria banyak menghadapi masalah dari dalam maupun dari luar sebagai konsekuensi pemilihan hidup sebagai waria. Mereka cenderung mangalami kebingungan mengenai identitas diri. selain itu adanya ketidakterimaan sosial dari lingkungan atas penentangan konstruksi gender. Mereka juga akan menghadapi betapa rumitnya legalitas. 
Hukum norma tertulis maupun tidak tertulis yang menempatkan pada hak dan kewajibannya serta mereka juga memiliki dorongan seksual yang sama dengan manusia lainnya (Lerner dan Spanier dalam Mardha, 2007).

Kegiatan komunikasi interpersonal merupakan kegiatan sehari-hari yang dilakukan oleh manusia sebagai makhluk social . dengan demikian kemampuan berkomunikasi merupakan suatu kemampuan yang paling dasar. Akan tetapi dalm kehidupan sehari-hari kita sering mengalami perbedaan pendapat ketidaknyamanan situasi atau bahkan terjadi konflik yang terbuka yang disebabkan adanya kesalahpahaman dalam berkomunikasi. Menghadapi situasi seperti ini, manusia baru akan menyadari bahwa diperlukan pengetahuan mengenai bagaimana cara berkomunikasi yang baik dan efektif harus dimiliki oleh seorang manusia. Kemampuan berkomunikasi interpersonal yang baik dan efektif sangat diperlukan oleh manusia agar dia dapat menjalani semua aktivitasnya dengan lancar. Terutama ketika seseorang melakukan aktivitas dalam situasi yang formal, misal dalam lingkungan kerja. Lebih penting lagi ketika aktivitas kerja seseorang adalah berhadapan langsung dengan orang lain dimana sebagian besar kegiatannya merupakan kegiatan komunikasi interpersonal. Dalam berkaitan dengan proses komunikasi interpersonal ada beberapa tipe komunikasi interepersonal yang dapat dilakukan antara lain (1) Komunikasi dua orang : yaitu mencakup segala jenis hubungan antarpribadi, antara satu orang dengan orang lain, mulai dari hubungan yang paling singkat (kontak) biasa, sampai hubungan yang bertahan lama dan mendalam. (2) Wawancara : merupakan salah satu tipe komunikasi interpersonal dimana dua orang terlibat dalam percakapan yang berupa Tanya jawab. (3) Komunikasi kelompok kecil : merupakan salah satu tipe komunikasi interpersonal, dimana beberapa orang terlibat dalam suatu pembicaraan, percakapan, diskusi, musyawarah, dan sebagainya

\section{METODE PENELITIAN}

Jenis penelitian ini adalah penelitian deskriktif, yaitu Penelitian Sosial Budaya yang dianalisis secara kualitatif, Penentuan informan dalam penelitian ini dilakukan secara sengaja (purposive sampling) yaitu informan kunci ( key informan), informan utama dan informan tambahan dan juga menggunakan sumber data primer dan data sekunder, teknik pengumpulan data yaitu wawancara mendalam, dan observasi partisipatif, kemudian dianalisis melalui tahapan pengumpulan data (data collection), reduksi data (data reduction), penyajian data 
(display data), penarikan kesimpulan (verification). Menggunakan trianggulasi, member chek, pemeriksaan sejawat, dan uraian rinci sebgai teknik keabsahan data.

\section{PEMBAHASAN}

\section{Eksistensi Komunitas Waria di Kabupaten Bantaeng}

Berdasarkan dari hasil wawancara bahwa Komunitas Waria di kota Bantaeng umumnya tinggal secara berkelompok Mereka bergaul dan berkawan hanya dengan teman-teman senasib, meskipun ada juga yang dapat berbaur dengan anggota masyarakat tanpa kendala. Menurut mereka, menjadi waria bukanlah hal yang menyeramkan atau bahkan bukan sesuatu hal yang dapat merugikan orang lain. Mereka beranggapan bahwa keberadaannya sama sekali bukan untuk mengganggu kehidupan orang lain dan tidak pernah berkeinginan untuk mengganggu kehidupan orang lain. kendala yang dialami waria kota Bantaeng karena tatanan sosial dan kultural belum sepenuhnya menempatkan waria sebagaimana sejajar dengan mereka yang berjenis kelamin yang dibedakan secara tegas, yakni laki-laki dan perempuan. Mereka tak pernah meminta di lahirkan sebagai waria dengan mendandani diri seperti wanita, mereka mendapatkan kenikmatan batin yang begitu dalam. ketika berhasil melepas beban psikologi yang selama ini masih memberatkannya. kebanyakan dari masyarakat masih belum dapat menerima, yang mempunyai kondisi terjebak dalam tubuh yang salah (para waria sering mengatakan bahwa mereka berjiwa wanita, tapi terjebak di tubuh pria). Pengalaman akan berbagai macam persoalan di dalam kehidupan waria kota bantaeng bukanlah sebuah cerita sederhana. Nasib menjadi waria kemudian menempa dan menciptakan mereka untuk menjadi sabar dan bijak dalam menghadapi hidup. Kondisi ini pula yang membuat wariawaria memiliki keterikatan emosional yang kuat diantara mereka sehingga menciptakan solidaritas mekanis diantara waria kota bantaeng. dalam teori salidaritas sosial David Emile Durkheim bahwa solidaritas mekanis didasarkan atas persamaan. Persamaan dan kecenderungan untuk berseragam inilah yang membentuk struktur sosial masyarakat segmenter dimana masyarakat bersifat homogen dan mirip satu sama lain. Apabila salah satu segmen itu hilang maka tidak akan berpengaruh besar terhadap segmen yang lainnya. Ciri masyarakat dengan solidaritas mekanis ini ditandai dengan adanya kesadaran kolektif dimana mereka mempunyai kesadaran untuk hormat pada ketaatan karena nilai-nilai keagamaan masih sangat tinggi.l 
Nasib menjadi waria kemudian menempa dan menciptakan mereka untuk menjadi sabar dan bijak dalam menghadapi hidup. Kondisi ini pula yang membuat wariawaria memiliki keterikatan emosional yang kuat diantara mereka sehingga menciptakan solidaritas mekanis diantara waria kota bantaeng. dalam teori salidaritas sosial David Emile Durkheim bahwa solidaritas mekanis didasarkan atas persamaan. Persamaan dan kecenderungan untuk berseragam inilah yang membentuk struktur sosial masyarakat segmenter dimana masyarakat bersifat homogen dan mirip satu sama lain. Apabila salah satu segmen itu hilang maka tidak akan berpengaruh besar terhadap segmen yang lainnya. Ciri masyarakat dengan solidaritas mekanis ini ditandai dengan adanya kesadaran kolektif dimana mereka mempunyai kesadaran untuk hormat pada ketaatan karena nilai-nilai keagamaan masih sangat tinggi. Waria yang pergi meninggalkan rumah, atau lari dari rumahnya dikarenakan menolak pilihan orang tua dan ketakutan untuk mengakui kewariaannya, kadang membawa hasil yang positif bagi para waria. Banyak waria ketika telah memilih lari dari rumah, pada suatu saat membuka pikiran orang tua waria untuk dapat menerima mereka kembali. Beberapa waria diterima kembali didalam keluarganya karena nurani sebagai orang tua telah tersentuh. Selain itu, bujukan dari anggota keluarga yang lain agar menerima mereka kembali ke dalam keluarga juga merupakan alasan lain seorang waria kembali diterima didalam keluarga. Hanya saja kasus ini tidak terjadi pada banyak waria, bahkan dapat dikatakan sebagai kasus langka yang dihadapi oleh komunitas waria di kota Bantaeng. Karena para orang tua tentunya tidak begitu senang dan merasa malu ketika mengetahui anaknya adalah seorang waria. jika menyangkut malu, sebagian besar orang tua waria memang merasa malu terhadap identitas waria yang mereka miliki, dan itu disadari pula oleh waria. Tingkat pendidikan waria kota bantaeng juga rata-rata relatif rendah. ini berimplikasi pada akses pekerjaan yang mereka bisa dapatkan terbatas pada hal-hal tertentu saja, itupun sesuai dengan ketrampilan dan keahlian yang mereka miliki. sebagian besar salon-salon yang ada di kota Bantaeng, penata riasnya adalah seorang waria dan mereka pun memiliki pelangan yang banyak walaupun sebagian masyarakat belum sepenuhnya menerima keberadaan mereka.

Ketika para waria diperhadapkankan pada kegiatan-kegiatan keagamaan tertentu. dalam agama islam, khususnya, yang di tegaskan membedakan tempat dan kedudukan untuk melakukan ibadah antara laki-laki dan perempuan. umumnya, sebagian waria menempatkan dirinya sebagai laki-laki tetapi adapun merasa malu ke tempat ibadah. Dalam praktik-praktik demikian, waria menempatkan diri sebagai laki-laki, sehingga ia akan memakai kopiah dan sarung serta menempati shaf laki-laki ketika shalat. 
Mereka menyadari bahwa ketika akan melakukan praktik-praktik ritual formal keagamaan, mereka akan kembali kepada fitrah biologisnya sebagaimana laki-laki.

\section{Bentuk Komunikasi Interpersonal Komunitas Waria di Kabupaten Bantaeng}

Pola komunikasi itu terbentuk dari kebiasaan, cara berinteraksi, pertukaran informasi, pengetahuan, dan symbol yang digunakan oleh komunitas waria sebagai bentuk komunikasi interpersonal dan juga sebagai bentuk eksistensi diri dikalangan masyarakat Kabupaten Bantaeng. Secara sederhana dapat dikemukakan suatu asumsi bahwa proses komunikasi interpersonal akan terjadi apabila ada pengirim menyampaikan informasi berupa lambang verbal maupun nonverbal kepada penerima dengan menggunakan medium suara manusia, maupun dengan medium tulisan. Bertolak dari defenisi diatas maka peneliti menjelaskan tentang bentuk komunikasi interpersonal komunitas waria dilingkungan masyarakat kota Bantaeng, dalam sub fokus peneliti mengaplikasikan kedalam bentuk nyata diantaranya:

1. Kebiasaan

Komunitas waria di Kota Bantaeng melakukan aktivitas sehari-hari mereka sebagai perias dan bekerja di salon atau belanja kebutuhan pribadinya, sedangkan pada malam hari mereka berkumpul bersama waria lainnya

2. Cara Berinteraksi

Cara berinteraksi waria pada umumnya menggunakan pola komunikasi formal yang biasanya digunakan ketika mereka berada dilingkungan keluarga, masyarakat ataupun lingkungan social lainnya, sedangkan pola komunikasi non-formal biasanya digunakan ketika mereka berada dalam lingkungan sesamanya.

3. Dimana pertukaran informasi tersebut tidak hanya bertukar informasi tetapi juga bisa bertukar pesan ataupun pikiran ataupun timbal balik yang positif dari proses tersebut dengan menggunakan komunikasi verbal serta media yang digunakannya. Pertukaran informasi komunitas waria kota Bantaeng yang di gunakan melalui bertemu langsung atau berkumpul bersama kaum waria lainnya adapun komunikasi lainnya dilakukan melalui media jejaring sosial seperti Facebook, Twitter serta Blackberry Messenger.

4. Pengetahuan

Proses dimana para waria mempresentasikan lingkungannya agar memberikan perlakuan terhadapnya secara efektif sesuai dengan tujuan, rencana, dan keinginan. Dalam hal ini mereka berpikir untuk mendapatkan sebuah pengakuan dari lingkungan baik dari wawasan, kreatifitas, dan berbagi pengetahuan.bahwa Pengetahuan yang mereka miliki tidak hanya seputar lingkungan sekitar tetapi mereka juga dibekali ilmu 
pengetahuan lainnya, bagi mereka pendidikan merupakan hal yang sangat penting bagi kehidupan mereka yang akan datang.

5. Simbol yang digunakan

Dalam hal ini para waria berusaha menyampaikan pesan yang ingin mereka sampaikan melalui simbol-simbol baik verbal maupun non verbal untuk dapat dipahami. Simbol yang digunakan waria di Kota Bantaeng yaitu melalui bahasa tubuh yang sering mereka lakukan, selain itu nama-pun menjadi sebuah simbol yang mencirikan jati diri mereka sebagai seorang waria, dan aksesoris yang mereka pakai saat berdandan layaknya seorang wanita-pun merupakan cara mereka untuk memberikan asumsi kepada lingkungannya bahwa mereka itu adalah seorang waria.

Kebiasaan, cara berinteraksi, pertukaran informasi, pengetahuan, symbol yang digunakan oleh komunitas waria sebagai cara untuk berinteraksi dan juga sebagai bentuk eksistensi diri dikalangan masyarakat Kabupaten Bantaeng yang merupakan konsep dalam penelitian ini.

Konsep fungsi mengindikatorkan bahwa waria mempunyai peranan dalam dirinya maupun dalam maysrakat. Peran waria di yogyakarta lewat organisasi kewariaanya memang udah terasa terutama dikalangan waria itu sendiri. waria sadar bahwa waria adalah suatu hal yang sah karena menjadi waria adalah kodarati yang tidak bisa dibuat buat. Dalam konteks waria masyarakat masih menganggap bahwa waria itu sesuatu yang hina, karena stigma yang beredar bahwa waria adalah pelaku seks abnormal, namun lewat simbol simbol berupa kegiatan positif dan memberi pemahaman tentang jiwa dan naluri kewariaan maka pelan pelan masyarakat akan memahami waria seperti apa yang waria inginkan. Hal ini di kaitkan dengan realitas waria yang mencari kebahagian menjadi waria, ini sebagai kepuasan batin orang tersebut sebagai keuntungan bagi dirinya sendiri. Yang kadang tidak memperdulikan lingkungan sekitar seperti keluarga dan orang orang yang menaggung malu disekitarnya, maskipun waria yang baik pelan pelan bisa diterima keberadaan di masyarakat. Nasib waria yang menempa dan menciptakan mereka untuk menjadi sabar dan bijak dalam menghadapi hidup. Kondisi ini pula yang membuat wariawaria memiliki keterikatan emosional yang kuat diantara mereka sehingga menciptakan solidaritas mekanis diantara waria kota Bantaeng.

\section{KESIMPULAN}


Dari hasil penelitian yang telah diperoleh, maka kesimpulan penelitian adalah sebagai berikut :

1. Dalam hal mempertahankan eksistensi komunitas waria kabupaten bantaeng mereka membentuk solidaritas mekanis yang ditandai dengan adanya kesadaran kolektif yang merasa senasib, dimana solidaritas ini merupakan kegiatan mempertahankan eksistensi mereka dalam berinteraksi sosial dengan lingkungan masyarakat yang mereka hadapi. Bentuk-bentuk solidaritas itu bisa dilihat dalam aktivitas ekonomi mereka yang kebanyakan bekerja di salon sebagai tukang cuku, penata rias pengantin dan tukan masak di pesta-pesta.

2. Bentuk komunikasi waria ada dua yakni bentuk terbuka dan tertutup dengan menggunakan media verbal dan non verbal. Bentuk inilah yang mendasari pola komunikasi yang terjadi dalam komunikasi interpersonal komunitas waria.

3. Pola komunikasi itu terbentuk dari kebiasaan, cara berinteraksi, pertukaran informasi, pengetahuan, dan simbol-simbol yang digunakan oleh komunitas waria sebagai bentuk komunikasi interpersonal dan juga sebagai bentuk eksistensi diri dikalangan masyarakat Kabupaten Bantaeng.

\section{DAFTAR PUSTAKA}

Koeswinarmo. (2004). Hidup Sebagai Waria. Yogyakarta: Lkis

Soerjono, Soekanto.(2013). Sosiologi Suatu Pengantar. Jakarta: Raja grafindo Persada.

Sugiono. (2014). Metode Penelitian Pendidikan Pendekatan Kuantitatif, Kualitatif, dan $R \& D$. Bandung: Alfabeta.

Indah, Mustikawati, dkk. (2013). Strategi Pemberdayaan Ekonomi Komunitas Waria Melalui Life Skill Education. .skripsi. Yogyakarta: universitas negeri Yogyakarta.

Mardha, Tresnowaty. (2007). Kesejahteraan Subjektif Waria Pekerja Seks Komersial (PSK). 2007.skripsi: universitas Gajah Mada.

Meta, Damariyanti. (2011). Agresivitas Kaum Male To Female Transeksual (waria). Skripsi: Universitas Gunadharma Yogyakarta.

Cahaya, Putra Nugraha. (2009). Proposal Penelitian Komunikasi II Pola Komunikasi Interpersonal Komunikasi Waria di Bank Indonesia. diakses di agung pers. blogspot.com. Tanggal 14 Juli 2014.

Dzulkifli, Assamarindi. (2011). Waria (Banci) dalam Syariat Islam. Artikel. di akses: $14 / 7 / 2014$ 
Denny, Bagus. Komunikasi Interpersonal: Defenisi, Kalasifikasi,Tujuan Dan Faktoryang Mempengaruhi Efektivitas Komunikasi Interpersonal. artikel: denny bagus.blogspot.com. di akses: 14/7/2014.

Hanger, Hidayanto. (2010). Waria dari segi social. Artikel: http//:hanggerh20. blogspot. com/2010/12/waria-dari-segi-sosial.html. di akses: 14/7/2014.

Juwilda. (2009). Transgender Manusia Keragaman dan Kesetaraannya. skripsi: universitas Sriwijaya diakses http://www.Google.com. di akses: 14/7/2014.

Muammar. (2011). Waria. artikel. diakses http://www.Google.com. di akses: 14/7/2014.

Widya, Pontoh,P. (2013). Peranan Komunikasi Interpersonal Guru Dalam Meningkatkan Pengetahuan Anak. Jurnal:'acta Diurma'Vol I.No.I.Tahun 2013. diakses http://www.Google.com. di akses: 14/7/2014 